\title{
Queer Kinship and
}

\section{Family Change in Taiwan}




\section{Families in Focus}

Series Editors

Naomi R. Gerstel, University of Massachusetts, Amherst

Karen V. Hansen, Brandeis University

Rosanna Hertz, Wellesley College

Nazli Kibria, Boston University

Margaret K. Nelson, Middlebury College

Katie L. Acosta, Amigas y Amantes: Sexually Nonconforming Latinas Negotiate Family

Riché J. Daniel Barnes, Raising the Race: Black Career Women Redefine Marriage, Motherhood, and Community

Ann V. Bell, Misconception: Social Class and Infertility in America

Amy Brainer, Queer Kinship and Family Change in Taiwan

Mignon Duffy, Amy Armenia, and Clare L. Stacey, eds., Caring on the Clock: The Complexities and Contradictions of Paid Care Work

Anita Ilta Garey and Karen V. Hansen, eds., At the Heart of Work and Family: Engaging the Ideas of Arlie Hochschild

Heather Jacobson, Labor of Love: Gestational Surrogacy and the Work of Making Babies

Katrina Kimport, Queering Marriage: Challenging Family Formation in the United States

Mary Ann Mason, Nicholas H. Wolfinger, and Marc Goulden, Do Babies Matter? Gender and Family in the Ivory Tower

Jamie L. Mullaney and Janet Hinson Shope, Paid to Party: Working Time and Emotion in Direct Home Sales

Markella B. Rutherford, Adult Supervision Required: Private Freedom and Public Constraints for Parents and Children

Barbara Wells, Daughters and Granddaughters of Farmworkers: Emerging from the Long Shadow of Farm Labor 


\section{Queer Kinship and Family Change in Taiwan}

AMY BRAINER

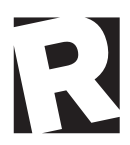

Rutgers University Press

New Brunswick, Camden, and Newark, New Jersey, and London 
Library of Congress Cataloging-in-Publication Data

Names: Brainer, Amy, author.

Title: Queer kinship and family change in Taiwan / Amy Brainer.

Description: New Brunswick : Rutgers University Press, [2018] | Series:

Families in focus | Includes bibliographical references and index.

Identifiers: LCCN 2018012993| ISBN 978081359761 4 (cloth) | ISBN 9780813597607 (pbk.)

Subjects: LCSH: Transgender children-Taiwan-Family relationships. |

Sexual minority youth-Taiwan-Family relationships.

Classification: LCC HQ77.95.T28 B73 2018 | DDC 306.7608350951249-dc23

LC record available at https://lccn.loc.gov/2018012993

A British Cataloging-in-Publication record for this book is available from the British Library.

Copyright $(2019$ by Amy Brainer

All rights reserved

Portions of this work appeared previously in "New Identities or New Intimacies? Reframing 'Coming Out' in Taiwan through Cross-Generational Ethnography," Sexualities 21, no. 5-6 (2018): 914-931; "Patrilineal Kinship and Transgender Embodiment in Taiwan," in Perverse Taiwan, ed. Howard Chiang and Yin Wang, I1O-I28 (New York: Routledge, 2017);

"Materializing 'Family Pressure' among Taiwanese Queer Women," Feminist Formations 29, no. 3 (2017): I-24; and "Mothering Gender and Sexually Nonconforming Children in Taiwan," Journal of Family Issues 38, no. 7 (2017): 921-947.

No part of this book may be reproduced or utilized in any form or by any means, electronic or mechanical, or by any information storage and retrieval system, without written permission from the publisher. Please contact Rutgers University Press, 106 Somerset Street, New Brunswick, NJ 0890 I. The only exception to this prohibition is "fair use" as defined by U.S. copyright law.

(2) The paper used in this publication meets the requirements of the American National Standard for Information Sciences-Permanence of Paper for Printed Library Materials, ANSI Z39.48-1992.

www.rutgersuniversitypress.org

Manufactured in the United States of America 
For Hotline 
